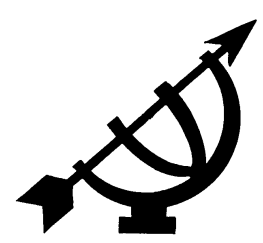

\title{
Islamic marriages in South Africa: Quo vadimus? ${ }^{1}$
}

Christa Rautenbach

Faculty of Law

North-West University

Potchefstroom Campus

POTCHEFSTROOM

E-mail: pvrcr@puknet.puk.ac.za

Abstract

Islamic marriages in South Africa: Quo vadimus?

Due to their potentially polygamous nature, Islamic marriages are not recognised in terms of South African law. The consequences of this non-recognition have been particularly unfair to Muslim women. Until 2000 a Muslim woman had no claim for loss of support if her husband was unlawfully killed. Even today she cannot claim maintenance from her husband after a divorce; she is not an intestate beneficiary after the death of her husband; can be compelled to give evidence against her husband in criminal proceedings and can not claim financial support during the course of her marriage. Since early times there have been calls for the recognition of Islamic marriages. The 1996 Constitution of South Africa protects, among other rights, cultural and religious rights and makes provision for the recognition of cultural and religious marriages by means of legislation. This article gives a brief historical overview regarding the position of Islamic marriages in South Africa. Thereafter the current position of Islamic marriages will be discussed, and finally a few comments regarding the future of Islamic marriages will be given.

Opsomming

Islamitiese huwelike in Suid-Afrika: Quo vadimus?

Die Suid-Afrikaanse reg ontken die geldigheid van Islamitiese huwelike as gevolg van die potensieel poligamiese aard daarvan. Die gevolge van dié nie-erkenning is besonder nadelig vir Moslemvroue.

1 Revised paper delivered at the Workshop on "Women in Church and Society" held at Potchefstroom, 6-8 May 2002. 
Tot en met 2000 kon sy nie onderhoud eis indien haar man onregmatig gedood is nie. Selfs vandag kan sy geen onderhoud van haar man na 'n egskeiding eis nie. Verder is sy nie 'n intestate erfgenaam na die dood van haar man nie; sy kan gedwing word om getuienis teen haar man in 'n kriminele saak af te lê en sy kan nie finansiële ondersteuning tydens haar huwelik eis nie. Sedert die vroegste tye was daar eise vir die erkenning van Islamitiese huwelike in Suid-Afrika. Die 1996 Grondwet beskerm onder andere kulturele en godsdienstige regte en maak voorsiening vir die erkenning van kulturele en godsdienstige huwelike by wyse van wetgewing. In hierdie artikel word 'n breë oorsig oor die geskiedenis met betrekking tot die erkenning van Islamitiese huwelike in Suid-Afrika gegee. Daarna word die huidige posisie bespreek en laastens word enkele opmerkings aangaande die toekoms van Islamitiese huwelike gemaak.

\section{Introductory remarks}

South Africa has been described as a "rainbow nation". Its population comprises a multicultural, multi-ethnic and multireligious society. The great majority of South Africans are Christians, although from various affiliations. Other religious minorities are also present: Muslims and Hindus (for example) constitute about two percent respectively and Jews less than half a percent of the total population. Adherents to Muslim, Hindu and Jewish religious legal systems live, to a large extent, according to unrecognised customs and practices. The rest of the so-called Western population is subject to the (mainly) secular laws of South Africa.

Since early times there have been calls for the recognition of certain aspects of religious legal systems and, in particular, for the recognition of Islamic marriages. ${ }^{2}$ The non-recognition of Islamic marriages was and still is a contentious issue in South Africa. Due to their potentially polygamous nature, Islamic marriages are not recognised as valid in terms of South African law. ${ }^{3}$ The tradition of

2 The attempts of the Muslim community to seek legal recognition of aspects of Islamic personal law finally led to the establishment of a Project Committee of the South African Law Commission in respect of its investigation into Islamic marriages and related matters. See South African Law Commission Islamic Marriages and Related Matters (Project 59). Up to date two discussion documents have been issued for comments, namely Issue Paper 15 and Discussion Paper 101.

3 Ismail $v$ Ismail 19831 SA 1006 (A). South African law is commonly referred to as South African common law. The development of South African common law, as the official legal system of South Africa is very interesting. In short its 
monogamous marriages, regarded as lawful in terms of RomanDutch law (referred to as civil marriages), and that was regarded as norm in South Africa since the time of the first Dutch settlers is, in general, the only marriages recognised as valid marriages. 4 This kind of marriage was and is still open to members of all the different population groups in South Africa. 5 Hahlo (1985:29) describes a marriage as "... the legally recognized voluntary union for life in common of one man and one woman, to the exclusion of all others while it lasts".

In this definition lies the first and most important reason for the nonrecognition of Islamic marriages in South Africa. Islamic marriages are not monogamous, but either de facto polygamous or potentially polygamous. According to South African common law, these marriages are contra bonos mores and therefore void.6 For an Islamic marriage to be recognised, it has to comply with the

development started with the establishment of a refreshment station by the Dutch East India Company (known as the "VOC") in 1652. As a natural result of the Dutch colonisation of the Cape the laws applicable to the settlers in the Cape were those outlined by Roman-Dutch law. These laws were official in the Netherlands at that stage. Roman-Dutch law applicable in the Cape started, however, to expand and develop in a different direction than Roman-Dutch law practices in the Netherlands. English law also influenced it after the British occupation in 1806. The influence was primarily in the form of legislation and court decisions. Today South African common law is a conglomerate of RomanDutch law, English law and legislation. For a further discussion of the history of South African common law, see Kleyn and Viljoen (2002: chapter 2).

4 The Recognition of Customary Marriages Act 120 of 1998, which came into effect on 15 November 2000, gives recognition to polygamous customary marriages. Despite section 15(3) of the Constitution of the Republic of South Africa 108 of 1996 (hereafter referred to as the 1996 Constitution) similar legislation has not been issued for the recognition of religious marriages.

5 The law of marriage in South Africa is a conglomerate of Roman-Dutch law and legislation. The legal requirements for a valid marriage according to RomanDutch law concern the contractual capacity of the spouses, consensus between the spouses and a lawful marriage. See Cronjé and Heaton (1999:21-47) for the requirements of a valid marriage. Furthermore, certain formalities as prescribed in the Marriage Act must be complied with. These formalities include, inter alia, the solemnisation of the marriage by a competent marriage officer in terms of section 11(1), the producing of identity documents and/or sworn affidavits by the parties in terms of section 12, the following of certain procedures at the marriage ceremony in terms of section 29 and the registration of the marriage in terms of section 29A. See Clark (1989:159-212) for a detailed discussion on the history of marriage in South Africa.

6 Seedat's Executors $v$ The Master (Natal) 1917 AD 302; Ismail v Ismail 19831 SA $1006(A)$. 
provisions of the Marriage Act 25 of 1961.7 The impediment against Islamic marriages does not only affect Islamic marriages contracted in South Africa, but also those contracted abroad.8

On 27 April 1994, South Africa entered a new constitutional dispensation with the commencement of the 1993 Constitution. ${ }^{9}$ The 1993 Constitution was repealed by the 1996 Constitution, which commenced on 4 February 1997. The 1996 Constitution recognises freedom of religion and makes provision for the recognition of religious and traditional marriages by means of legislation. ${ }^{10}$

The 1996 Constitution also recognises the religious diversity of the South African population and opens the door for the future recognition of Islamic marriages.11 It is clear from these provisions that Muslim people have the right to enjoy their culture and to practise their religion. The right to have Islamic marriages 12 recognised is, however, not constitutionalised in the 1996 Constitution. 13

$7 \quad$ Hereafter referred to as the Marriage Act. For example, in terms of section 11 of the Act a marriage must be solemnised by an appointed marriage officer. If the Imam is not an appointed marriage officer, he would not be in a position to solemnise a valid marriage in terms of the Act. Such a person may, however, receive an appointment as a marriage officer. See Sinclair (1996:263-266).

8 Thus an Islamic marriage concluded as a valid marriage in Pakistan between two Pakistanis will not be recognised as a valid marriage in South Africa. The non-recognition of Islamic marriages contracted abroad has various implications for Muslims who live in South Africa. Their marriages are not recognised and therefore the normal legal effects of such marriages are also not recognised.

9 Constitution of the Republic of South Africa 200 of 1993 (hereafter referred to as the 1993 Constitution).

10 Freedom of religion was recognised in terms of section 14 of the 1993 Constitution.

11 Section 15 (freedom of religion, belief and opinion), read with sections 30 (right to language and culture), 31 (rights of cultural, religious and linguistic communities), 181(1)(c) (establishment of the Commission for the Promotion and Protection of Cultural, Religious and Linguistic Communities) and 185 (objects and functions of the Commission).

12 There has been constant pressure on the Government to recognise Islamic personal law. See Moosa (1996:41 et seq). Islamic personal law includes the marriage and succession laws of Muslims.

13 The position was the same under the 1993 Constitution. See De Waal, Currie and Erasmus (2001:308). 
Furthermore, certain provisions of the 1996 Constitution seem fraught with potential conflict.14 For example, according to the Islamic law of divorce, a Muslim husband may divorce his wife by uttering the word talaaq three times. The same option is, however, not available to a Muslim wife. This Islamic law seems to be in direct conflict with the right to equality. However, it may be argued by some that such discrimination is sanctioned in terms of the provisions that recognise religious and cultural rights so that such discrimination is consequently not unconstitutional. ${ }^{15}$

This article may be divided broadly into three sections. Firstly, a brief historical overview regarding the recognition of Islamic marriages in South Africa will be given (see $\S 2$ ). Thereafter, the current position regarding Islamic marriages will be discussed (see $\S 3$ ). Finally, a few concluding remarks regarding the future of Islamic marriages in the light of the 1996 Constitution and the proposals of the South African Law Commission will be given (see $§ 4$ and 5).

\section{Historical background}

The majority of Muslims who first arrived in the former Cape Colony was brought from Dutch colonies in the East Indies (now Indonesia), the coastal regions of Southern India and Malaysia as slaves, convicts and political exiles. Later they were also imported from India to work on the sugar plantations of the former Natal Province (later renamed KwaZulu-Natal) and some of them also came as

14 See sections 15, 30, 31, 181(1)(c), 185, 187 and 9. Section 9 is referred to as the equality-clause. Section 9(1) confirms that every individual "is equal before the law and has the right to equal protection and benefit of the law". Section 9(2) deals with measures to effect so-called "affirmative action". Section 9(3) prohibits unfair discrimination by the State on the grounds of race, gender, sex, pregnancy, marital status, ethnic or social origin, colour, sexual orientation, age, disability, religion, conscience, belief, culture, language and birth. Section 9(4) prohibits unfair discrimination between individuals on the same grounds and authorises the national legislature to enact legislation to prohibit unfair discrimination. In terms of section 9(5) discrimination in terms of subsection (3) is unfair unless it is proven that the particular discrimination is fair. The onus is thus on the person/state who alleges that the discrimination is fair.

15 According to Goolam (1996:752-753), cognisance must be taken of the different value systems of the various communities before human rights issues are debated. He argues: "In order to understand the approach adopted by any particular culture or civilisation in respect of the issue of gender equality, it is necessary to understand the culture's or civilisation's total approach to human existence. In this way, a solution to a specific problem is correctly viewed in its larger and complete setting." 
businessmen. Although the Dutch colonials prohibited the practice of Islam in public places or the conversions of heathens or Christians to Islam, the English colonials gave them religious freedom in 1806.16

Although religious freedom has existed in South Africa from an early stage, it did not mean that de facto or potentially polygamous religious marriages were recognised as valid marriages. From an early stage and as a general rule these marriages were regarded as contra bonos mores and thus void. The consequence was that the wife of such a union was not recognised as a "wife" in terms of South African law and the children born out of such a union were regarded as extra-marital. ${ }^{17}$

Due to the large influx of Indian immigrants of whom a large section was Muslims, some of the provinces made provision for different marriage and immigration laws regarding Indians. 18 However, these marriages had to be monogamous before they could receive

16 Much has been written about the settlement of Muslims in South Africa. For a brief summary see Moosa (1996:35 et seq).

17 Bronn v Frits Bronn's Executors (1860) 3 Searle 313; $R$ v Sukina 1912 TPD 1079; Esop v Union Government (Minister of the Interior) 1913 CPD 133. In the former Transvaal in R v Fatima 1912 TPD 59 the court held that "wife" included the wife of an Indian immigrant who was married in terms of religious rites that were not recognised as a valid marriage in terms of the laws of Transvaal. "Wife" was, however, restricted to only one wife of an Indian immigrant. In terms of section 1 of the Births and Deaths Registration Amendment Act 40 of 1996, the children born from such an invalid marriage are no longer regarded as extra-marital. Although section 2 of the same Act defines "marriage" as to include a religious marriage, it does not give recognition to Islamic marriages.

18 For example, in the former Cape Colony section 4 of the Marriage Act 16 of 1860 (C) made provision for marriage officers to be appointed to solemnise monogamous Islamic marriages. See Mashia Ebrahim v Mahomed Essop 1905 TS 59. The particular Act was repealed by the Marriage Act. In terms of section 4(e) of the Immigration Act 30 of 1906 (C) provision was also made for the exemption of the wife of an exempted Indian immigrant. In Esop $v$ Union Government (Minister of the Interior) 1913 CPD 133 the court held that "wife" in terms of the said Act did not include a woman married in terms of Islamic law that recognises polygamy. The particular Act was repealed by the Immigrants Regulation Act 22 of 1913. In the former Natal the marriages of Muslims were regulated in terms of Law 19 of $1881(\mathrm{~N})$. The Indian Immigration Law 25 of $1891(\mathrm{~N})$ made provision for the registration of the marriages of Indian immigrants. These two acts were both repealed by the Marriage Act. No provision was made in the former Transvaal and Orange Free State for the regulation of Islamic marriages. For a detailed historical discussion of the various legislation applicable to marriages in South Africa see an earlier edition of Hahlo (1963:16 et seq, 62 fn 2, 583-585). 
recognition. The only province that made provision for the recognition of polygamous Indian marriages was the former province of Natal.19 Such recognition was only given to Indian marriages concluded before arrival in South Africa. These marriages became valid upon registering them by the then Protector of Indian Immigrants. Indian immigrants domiciled in South Africa could not conclude valid polygamous marriages in South Africa or anywhere else after they had established their domicile in South Africa.20

The Immigrants Regulation Act 22 of $1913^{21}$ consolidated and amended the various immigration laws that existed in the provinces.22 The main purpose of the Act was to regulate the affairs of immigrants. It made provision for certain persons or classes of persons to be exempted as prohibited immigrants. In terms of the Act a wife of an immigrant who was in a "lawful and monogamous marriage duly celebrated according to the rites of any religious faith outside the Union" was also exempted as a prohibited immigrant (see section $5(\mathrm{~g})$ ). The effect of this provision was very harsh on Indian immigrants who were married in terms of Islamic law, because such a marriage was not necessarily "lawful and monogamous".

In 1914 the Indian Relief Act 22 of 1914 brought some respite. The reference to a "lawful and monogamous marriage duly celebrated according to the rites of any religious faith outside the Union" was deleted (see section 3(1)). "Wife" was defined so as to include one wife of a polygamous marriage. 23 It made provision for the

19 Section 68 of the Indian Immigration Law 25 of $1891(\mathrm{~N})$ as repealed by the Marriage Act.

20 Section 66 of the Indian Immigration Law 25 of $1891(\mathrm{~N})$ as repealed by the Marriage Act.

21 It commenced on 1 August 1913. In terms of section 5 of the Admission of Persons to the Union Regulation Amendment Act 60 of 1961 the title of this Act was changed to the Admission of Persons to the Union Regulation Act 22 of 1913. The Admission of Persons to the Republic Regulation Act 59 of 1972 repealed this act, which was in turn repealed by the Aliens Control Act 96 of 1991.

22 See section 29 read with the first schedule of the Act for the laws that were repealed.

23 See section 3(2). The marriage had to be recognised as a valid marriage under the tenets of an Indian religion. "Wife" included, however, only any one woman to whom the exempted male was married (Hahlo, 1963:585). 
appointment of priests of any Indian religion as marriage officers. They were authorised to conclude Indian marriages according to the rites of any Indian religion (see section 1). Such a marriage could be transformed into a valid marriage if it was registered (see section 2). In order to be registered, the marriage had to be recognised as a marriage under the tenets of the particular religion and had to be a de facto monogamous marriage. However, the incidents that followed from such a marriage were identical to the incidents that followed from a valid civil marriage (see section 1(2)). The General Law Amendment Act 80 of 1971 repealed the Indian Relief Act and, since 1971, it is no longer possible to conclude a valid Indian marriage in this way.

Furthermore, foreign polygamous marriages were and still are not recognised as valid marriages in South Africa. The locus classicus in this regard is Seedat's Executors $v$ The Master (Natal) 1917 AD 302. The facts of this case may be summarised as follows: $H$ married W1 in 1883 while domiciled in India. Three children were born in India out of this marriage. In 1902 he immigrated to South Africa and settled in the former Province of Natal. In 1904, while domiciled in Natal, he went back to India and married W2. Six children were born out of his second marriage, two in India and four in Natal. $\mathrm{H}$ died leaving a will in which he bequeathed his estate to his two wives and all his children according to Islamic law. Under the Natal Act 35 of 1905 the "lineal descendants" of the testator must pay $1 \%$ estate tax and all other beneficiaries 5\%. The "surviving spouse" of the testator was exempt from paying estate tax. It was, therefore, essential to determine whether H's wives were "surviving spouses" and his children "lineal descendants" in terms of the Act. It was accepted that H's second marriage was void and his children therefore extra-marital. He was domiciled in Natal and could, therefore, not have concluded a valid polygamous marriage in India. However, regarding H's first marriage it was argued that such a marriage was valid in terms of the law of domicile (that was India) and should, therefore, also be recognised as a valid marriage in terms of South African law. The court found that it is under no obligation to recognise a marriage contracted validly in terms of foreign law if such a marriage would be "repugnant to the moral principles of its people" (at 307).

The court held that polygamy ... vitally affects the nature of the most important relationship into which human beings can enter. It is reprobated by the majority of civilized peoples, on grounds of 
morality and religion ${ }^{24}$, and the Courts of a country which forbids it are not justified in recognizing a polygamous union as a valid marriage. 25

The court held that W1 was not a "surviving spouse" in terms of the said Act and that she had to pay $5 \%$ estate tax. However, since the status of their children was determined in terms of domicile of religion, they were legitimate in India and, therefore, also in South Africa. The children of $\mathrm{H}$ and $\mathrm{W} 1$ were "lineal descendants" in terms of the said Act and only liable to pay $1 \%$ estate tax.

On 1 January 1962, the Marriage Act came into operation. It is a consolidation of all existing marriage laws and some immigration laws in South Africa. "Marriage" is not defined in terms of the Act and it is generally accepted that it means a civil marriage. The Act makes provision for the appointment of a marriage officer with authority to solemnise a marriage "according to Christian, Jewish or Mohammedan rites or the rites of any Indian religion" (at 307-308). 26 Section 29A further makes provision for the registration of such a marriage by the marriage officer. Islamic marriages will, therefore, be regarded as valid monogamous marriages if they were solemnised by an authorised marriage officer and if the particular marriage was registered (Hahlo, 1985:31-32).27 The Marriage Act makes it possible for a void de facto monogamous Islamic marriage to be converted into a valid civil marriage. The conversion means, however, that South African common law applies to such a marriage and it is, therefore, unacceptable to most Muslims.

24 Own emphasis. Sixty six years later the court in Ismail $v$ Ismail 19831 SA 1006 (A) 1026A-B concurred with this judgement. However, the court in the Ismail case did not say that an Islamic marriage was contra bonos mores in a narrow sense, that is, immoral, but held that such a union is contra bonos mores in a wider sense, that is "contrary to the accepted customs and usages which are regarded as morally binding upon all members of our society ... or 'as being fundamentally opposed to our principles and institutions'". This is a clear shift in the court's attitude towards the reason given for the invalidity of a polygamous marriage. The reason shifted from being regarded as unchristian to it being regarded against accepted customs and usages.

25 It is irrelevant if such a marriage is de facto monogamous or not.

26 See section 3. It has been found that the clause "according to Christian, Jewish or Mohammedan rites or the rites of any Indian religion" does not authorise the conclusion of potentially polygamous unions in terms of Islamic law. See Ismail $v$ Ismail 19831 SA 1006 (A) 1021A-C.

The Act also prescribes other formalities for valid marriages. 


\section{Islamic marriages today}

Although Muslims constitute only about $2 \%$ of the total population of South Africa, 28 they regard adherence to their religion in a very serious light. In general Muslims feel that they have the right to regulate their lives in terms of their own legal system, that is Islamic personal law (Moosa, 1995:19-22). This means that Muslims also seek recognition of their marriages and the consequences flowing therefrom. However, legislature and the attitude of courts have not been sympathetic towards this plight of Muslims in South Africa since the commencement of the 1993 and 1996 Constitutions. These constitutions still do not recognise Islamic marriages as valid marriages.

Courts did, in some cases, declare Islamic marriages as putative marriages. ${ }^{29}$ However, in order to be declared a putative marriage, it must be proved that one or both of the parties acted in good faith. Although an Islamic marriage is regarded as void, it has certain of the effects of a valid marriage. For example, the children of a putative marriage have the same status as the children born from a valid civil marriage (Hahlo, 1985:111-117).

In 1983 the court of appeal interpreted the provisions of the Marriage Act in Ismail $v$ Ismail 19831 SA 1006 (A). The facts of the case may be summarised as follows: $H$ and $W$ were married in terms of Islamic law. Their marriage was at all material times monogamous. Approximately four years after their marriage $\mathrm{H}$ divorced $\mathrm{W}$ by means of talaaqi.30 W claimed for arrear maintenance 31 , the delivery of deferred dowry, payment of certain

28 In 1991 there were 389573 Hindus, 338142 Muslims and 67654 Jews from a population of 30986920 people in South Africa. See Central Statistical Services Report 03/01/22 - Population Census 1991. There are also other statistics available that differ somewhat from the statistics of the Central Statistical Services. The difference is, however, of no great importance. See Moosa (1996:39-40); Haron (1997:1).

29 See, inter alia, Moola v Aulsebrook No 19831 SA 687 (N); Ex Parte Azar 1932 OPD 107; Ex Parte L 19473 SA 50 (C). However, in Solomons v Abrams 1991 4 SA 437 (W) the court refused to declare a Islamic marriage as a putative marriage. The court held that only a ceremony that has been duly solemnised in terms of the Marriage Act could be regarded as a valid marriage.

30 If the talaaqi (meaning "I divorce you") is communicated three times at certain stages by a husband to a wife the marriages comes to an end.

31 She alleged that $\mathrm{H}$ did not maintain her during the last two years and ten months of their marriage. 
jewellery in W's possession and maintenance for the period of Iddat32 in the Moulana33. The Moulana gave judgement in favour of $\mathrm{W}$. $\mathrm{H}$ neglected to abide by the judgement and $\mathrm{W}$ instituted action in the Transvaal Provincial Division. $\mathrm{H}$ raised a point in limine against her particulars of action:

[i]nasmuch as the customs relied upon by the plaintiff [W] are contra bonos mores, unreasonable and in conflict with law, alternatively are in conflict with rules of law which are unalterable by agreement (at 1019E-F).

The exception was upheld in the court a quo and it was found that the marriage was polygamous and, therefore, void on the grounds of public policy. The court argued that to “... entertain the plaintiff's [W's] claims would be tantamount to recognising the illegal union entered into by the parties and that would be to fly into the face of all authority in this country ... (at 1019F-G) ".

W lodged an appeal against this decision. The Appellate Division had to decide whether the court a quo erred in upholding the point in limine of $\mathrm{H}$. In order to do so, the validity of the marriage between $\mathrm{H}$ and $\mathrm{W}$ had to be investigated.

W's counsel agreed that the marriage was not valid because it is potentially polygamous and did not comply with the formalities of the Marriage Act (see sections 2, 3, 11 \& 29(2) of the Act). ${ }^{34}$ They argued that W's cause of action was based on certain Islamic customs and a marriage contract and not on the marriage between the parties. The question that had to be considered was whether the Islamic customs and a contract arising from them are contra bonos mores and not whether the marriage was valid or void. The court did not agree with this approach and thus stated:

In my view the claims should not be viewed in isolation. The tenets of the Muslim faith appear to govern all aspects of the marriage relationship. ... the Court must have regard to the very close and intimate connection between the customs and contract in question and the underlying conjugal union (1020D-F).

32 Iddat refers to a waiting period that starts after the husband has pronounced the divorce, which is more or less three months after the divorce (Moosa, 1998:198).

33 The Moulana is an Islamic authority in Pretoria, South Africa, whose judgement is only binding upon the conscience of Muslims in South Africa. 
The second argument submitted by W's counsel was the change in the attitude of society towards polygamy. In order to illustrate this submission W's counsel relied on a few factors. First of all they argued that the provisions of sections 3(1) and 11 of the Marriage Act afforded Islamic marriages some form of recognition. Section 3(1) reads:

The Minister and any officer in the public service authorized thereto by him may designate any minister of religion of, or any person holding a responsible position in, any religious denomination or organization to be, so long as he is such a minister or occupies such position, a marriage officer for the purpose of solemnizing marriages according to Christian, Jewish or Mohammedan rites or the rites of any Indian religion.

The court was of the opinion, however, that section 3(1) did not afford any recognition to Islamic marriages. It found that the emphasised words related to the form of the marriage ceremony and not to the requirements of the marriage as such. Section 3(1) enables Muslims to conclude their marriages according to Islamic rites by an Imam. If, however, they want their marriages to be valid monogamous marriages in terms of South African law, the Imam must be a designated marriage officer who has to comply with the formalities applicable to the solemnisation of marriages in terms of the Act.

Furthermore, W's counsel argued that section 11 gave some form of recognition to Islamic marriages, because such marriages do not "purport to effect a valid marriage" in terms of subsection 3. Section 11 reads as follows:

(a) A marriage may be solemnized by a marriage officer only.

(b) Any marriage officer who purports to solemnize a marriage which he is not authorized under this Act to solemnize or which to his knowledge is legally prohibited, and any person not being a marriage officer who purports to solemnize a marriage, shall be guilty of an offence and liable on conviction to a fine not exceeding four hundred rand or, in default of payment, to imprisonment for a period not exceeding twelve months, or to both such fine and such imprisonment.

(c) Nothing in sub-section (2) contained shall apply to any marriage ceremony solemnized in accordance with the rites or formularies of any religion, if such ceremony does not purport to effect a valid marriage. 
The court evaluated section 11 and found that there was nothing in the provisions of section 11 that gives some form of recognition to Islamic marriages. It held:

The mere fact that the Legislature has not prohibited polygamous unions, recognised as marriages under the tenets of the Muslim faith, does not mean it also approves of such unions or that the consequences thereof are legally enforceable (at $1021 \mathrm{H}-1022 \mathrm{~A}$ ).

In the third place W's counsel referred the court to English and Zimbabwean cases to illustrate that increased recognition was given to polygamous marriages in England and Zimbabwe. The court held, however, that those cases referred to foreign polygamous marriages and were, therefore, distinguishable from the facts of this case (at 1022B-1023H).

Fourthly, W's counsel argued that the legislature, in a number of statutes, gave recognition to polygamous marriages. The court evaluated these statutes and came to the conclusion that the existence of such legislation was not indicative of recognition (or "tolerance" as the court called it) of Islamic marriages in general (at 1024C-D).

The court finally came to the conclusion that the marriage of $\mathrm{W}$ and $\mathrm{H}$ was contra bonos mores and thus void on the following grounds (at 1024D-1026B):

- There was no justification to deviate from the long line of decisions in which the courts had refused to give recognition to Islamic marriages.

- The concept of polygamous marriages would undermine the monogamous status of civil marriages.

- The marriage laws of South Africa were designed for monogamous marriages and recognition of polygamous marriages would create practical problems. ${ }^{35}$

35 The concept of polygamous marriages is not unfamiliar to the South African law system. Discretionary recognition has been given to polygamous customary law unions in terms of section 1(1) of the Law of Evidence Amendment Act 45 of 1988. Furthermore, the Recognition of Customary Marriages Act 120 of 1998 gives formal recognition to polygamous customary law unions. 
- The recognition of Islamic marriages would be in conflict with the principle of equality between marriage partners. ${ }^{36}$

- Muslims had the right to convert their de facto monogamous marriages into de jure monogamous marriages in terms of the provisions of the Marriage Act.

- Islamic marriages were "contrary to the accepted customs and usages that were regarded as morally binding upon all members of society" (at 1026B).

As a result of the marriage of $\mathrm{H}$ and $\mathrm{W}$ being void, all Islamic customs and the contract arising from their marriage were also contra bonos mores and void. The court held accordingly that the appeal regarding W's claim for arrear maintenance, deferred dowry and maintenance for the period of Iddat should fail. The claim for certain jewellery, which was the property of $\mathrm{W}$, did not rely on the same grounds as the other claims and had to succeed (At 10261027).

The consequences of the non-recognition of Islamic marriages have been particularly unfair to Muslim women. Until 2002 she had no claim for loss of support if her husband was unlawfully killed37. Even today she cannot claim maintenance from her husband after a divorce 38; is not an intestate beneficiary after the death of her husband in terms of the Intestate Succession Act 81 of 198739; can be compelled to give evidence against her husband in criminal

36 For example, a Muslim wife does not participate in the marriage ceremony and a Muslim husband may terminate the marriage unilaterally, whilst a Muslim wife is not in the position to do so $(1024 \mathrm{G}-\mathrm{H})$. Although this might be true, the nonrecognition of the marriage in casu also resulted in the prejudice of a wife in that she could not claim for maintenance.

37 Amod v Multilateral Motor Vehicle Accident Fund 199712 BCLR 1716 (D). Fortunately the supreme court of appeal developed the common law claim for loss of support to include the claim of a Muslim widow involved in a de facto monogamous Islamic marriage. See Amod v Multilateral Motor Vehicle Accident Fund (Commissioner for Gender Equality Intervening) 19994 SA 1319 (SCA).

Ismail v Ismail 19831 SA 1006 (A).

39 In terms of the Act, the "spouse" of a deceased person inherits from the deceased's intestate estate if the latter dies intestate. "Spouse" includes only a spouse to whom the deceased was married in terms of civil law, and spouses of Islamic marriages are not regarded as spouses in terms of the Act. Seedat's Executors v The Master (Natal) 1917 AD 302; Davids v The Master 19831458 (C). 
proceedings 40 and can not claim financial support during the course of her marriage (Cachalia, 1991:22). The question may be asked whether the provisions of the 1996 Constitution altered the position regarding the recognition of Islamic marriages. A discussion of the relevant provisions of the 1996 Constitution follows hereafter.

\section{Islamic marriages and the South African Constitution}

\section{1 Introduction}

As already explained, religious communities in South Africa follow religious practices that are, at this stage, not formally recognised in terms of South African law. The result is that adherents of religious legal systems live under state law in the public sphere, which is the common law and, with regard to their private life, according to nonstate law, which is religious customs and usages. It is important to determine the applicability of the 1996 Constitution, and in particular, the Bill of Rights to unrecognised religious legal systems, which are unofficially in operation in South Africa. The answer to this issue is of importance to Muslim women adhering to Islamic personal law. Can they rely on the provisions of the 1996 Constitution for protection?

The issue of the applicability of the Bill of Rights is closely connected to the meaning of "law" within certain sections of the 1996 Constitution (see section $2 \& 8(1)$ ). Section 2 invalidate any "law or conduct" that is inconsistent with the Constitution and section 8(1) subjects "all law" to the provisions of the Bill of Rights. The meaning of law has been narrowed down to include only common law, customary law and statutory law (Rautenbach, 2000: 303-304). The implication is that unrecognised religious legal systems seem to be excluded from the scrutiny of the Bill of Rights 41.

It is therefore recommended that recognition must be given to Islamic personal law, or at least to Islamic marriages. There are at least two possible ways to recognise Islamic marriages. The first is to develop common law to recognize Islamic marriages, and the

40 In terms of section 195 of the Criminal Procedure Act 51 of 1977, a wife or husband may not be compelled to testify against each other in a criminal case. A Muslim wife or husband is, however, not entitled to invoke such privilege. See $S v$ Johardien 19901 SA 1026 (C).

41 See Rautenbach (2002:116-118) for a detailed discussion of her arguments in favour of the inclusion of religious legal systems in the definition of "law". 
second is to give legislative recognition to Islamic marriages in terms of section 15(3) of the 1996 Constitution. These two possibilities will be discussed in the following paragraphs.

\subsection{Development of common law}

The first option is to develop the common law in order to recognise Islamic marriages. The 1996 Constitution empowers courts to develop common law. Such development must promote the spirit, purport and objects of the Bill of Rights. The indirect horizontal application of the Bill of Rights implies that the common law must be developed through the principle of the boni mores. Up to now courts have held that Islamic marriages are potentially polygamous and are therefore contra bonos mores. Today, however, various sections in the 1996 Constitution guarantee religious freedom. Since the "spirit, purport, and objects" of the Bill of Rights must be promoted when common law is interpreted, it may be argued that the nonrecognition of Islamic marriages is unconstitutional in the light of our constitutional values of equality and freedom. According to Corbett et al. (1980:67)

... the policy decisions of our courts which shape and, at times, refashion the common law must also reflect the wishes, often unspoken, and the perceptions, often but dimly discerned, of the people.

Through the years there have been attempts to develop common law to give recognition to Islamic practices or customs followed in South Africa. Ryland v Edros 19971 BCLR 77 (C) and Amod v Multilateral Motor Vehicle Accident Fund 199712 BCLR 1716 (D) serve as recent illustrations of these attempts. In Ryland $v$ Edros $\mathbf{4 2}$, the court was prepared to develop common law to give recognition to the contractual consequences of an Islamic marriage. The facts of the case were as follows: $\mathrm{H}$ and $\mathrm{W}$ entered into a de facto monogamous Islamic marriage in 1976. Their marriage did not comply with the provisions of the Marriage Act and was, therefore, not a valid recognised marriage in terms of the said Act. $\mathrm{H}$ divorced W in 1992 by serving the talaaqi on her. Thereafter he instituted an action in court to evict her from the house that they shared as husband and wife. W defended the action and instituted a counter-

42 The case was decided when the 1993 Constitution was still in force. However, section 14 of the 1993 Constitution is similar to section 15 of the 1996 Constitution, and the decision is still relevant to the interpretation of the 1996 Constitution. 
claim for arrear maintenance (for the period of their marriage), a consolatory gift 43 and an equitable portion of the growth of H's estate $^{44}$. She based her claim on the "contractual agreement" constituted by their Islamic marriage. During the pre-trial proceedings $\mathrm{H}$ and $\mathrm{W}$ agreed that $\mathrm{W}$ would vacate the house and that $\mathrm{H}$ would pay half of W's costs with regard to her counter-claim. The only issue on which the court had to decide was W's counterclaim.

In order to reach a decision regarding W's counter-claim, the court had to answer two preliminary questions. The first question was whether it was appropriate for the court to pronounce upon religious matters ${ }^{45}$. Farlam $\mathrm{J}$ pointed out that courts, in the past, did not involve themselves in religious matters "unless some proprietary or other legally recognised right was involved." $46 \mathrm{He}$ argued that section 14 of the 1993 Constitution 47 might have changed the position and that the doctrine of entanglement might now be part of South African law. However, since the representatives of $\mathrm{H}$ and $\mathrm{W}$ agreed that the present issues did not require the interpretation of religious issues, there was no question of doctrinal entanglement. It was, therefore, not necessary for the court to deal with the question. 48

The second question was whether the Ismail case prevented $\mathrm{H}$ and $\mathrm{W}$ from relying on the marriage contract that formed the basis of their Islamic marriage. Farlam $\mathrm{J}$ held that public policy was a question of fact. 49 Because public policy is based on facts, it can

43 W alleged that the divorce was without just cause. 696G.

44 W alleged that she contributed labour, effort and money to H's estate and that she is therefore entitled to an equitable portion thereof. $696 \mathrm{H}$.

45 Farlam J Refers to it as the "doctrine of entanglement."

46 703E. Quoted from Allen v Gibbs 19773 SA 212 (SE) 218A-B.

47 The wording of section 13 of the 1993 Constitution is similar to the wording of section 15 of the 1996 Constitution.

48 703B-J. It may, however, be argued that the court did indeed interpret religious issues by choosing the evidence of one expert witness over the other on the issue of the division of property between the parties (715-714).

49 At 704B. He referred to the 1993 Constitution, which was the beginning of the new South African constitutional dispensation. According to Mahomed (1997:189) it is clear that the concept of public policy is not a vague and arbitrary concept that is " ... open to abuse by an executive-minded judiciary. 
only change if there is a change in the facts on which it is based. He accepted that the 1993 Constitution brought about a change in the factual position of public policy in South African common law and it was possible to revise the Ismail case regarding the validity of a contract flowing from an Islamic marriage. The 1993 Constitution required a reappraisal of the basic values on which public policy was based. If the "spirit, purport and objects" of the 1993 Constitution and the basic values underlying it were in conflict with the view regarding public policy, as expressed in the Ismail case, then the values underlying the 1993 Constitution had to prevail.

The court then considered whether the underlying values of the 1993 Constitution were in conflict with the views regarding public policy as expressed in the Ismail case. Farlam $\mathrm{J}$ came to the conclusion that it could not be said that the contract arising from a Islamic marriage was "contrary to the accepted customs and usages which are regarded as morally binding upon all members of our society" or was "fundamentally opposed to our principles and institutions" as expressed in the Ismail case. He based his decision on, inter alia, the fact that the viewpoints of only one group in our multicultural society were taken into consideration and found:

[l]t is quite inimical to all the values of the new South Africa for one group to impose its values on another and that the Courts should only brand a contract as offensive to public policy if it is offensive to those values which are shared by the community at large, by all right-thinking people in the community and not only by one section of it (707G).

Secondly, Farlam $\mathrm{J}$ referred to the principles of equality and of diversity and the recognition of the South African society as a multicultural society. These principles were among the values that underlined the 1993 Constitution. In his opinion these values "irradiate" the concept of public policy that the courts have to apply. He differed from the viewpoint expressed in the Ismail case, that is that the contracts in issue were contra bonos mores and held:

In my opinion the 'radiating' effect of the values underlying the new Constitution 50 is such that neither of these grounds for holding the contractual terms under consideration in this case to be unlawful can be supported (at 709C).

Rather it operates within definite parameters and is guided by the interpretation provision ..." of the 1993 Constitution. 
Finally he came to the conclusion that the marriage, as well as the contract arising from the marriage, were not contra bonos mores. The result was that the Ismail case no longer "operates to preclude a court from enforcing claims such as those brought by" parties to an Islamic union. The court then proceeded to consider the counterclaim of $\mathrm{W}$ and awarded her arrear maintenance after considering the facts. 51 The question of whether $W$ was entitled to a consolatory gift stood over for later determination.52 Regarding the claim for an equitable share in H's estate, the court found that $\mathrm{W}$ could not prove that such a custom existed among the Muslim population and that her claim had to fail. 53

Although this case is seen as a landmark case regarding the rights of Muslims in South Africa, its effect is limited in three ways. Firstly, no recognition has been given to Islamic marriages. It is only the marriage contract that arises from a Islamic marriage that is

51 At 711D-714F. W claimed arrear maintenance from January 1977 (date of marriage) to 14 January 1993 (third month after third talak was served). The court pointed out that the parties concluded a contract in terms of which they agreed that their marriage would be governed by Islamic law. It was common cause that the rules of the Shafi'i school is relevant in this case. Under the Shafi'i school $\mathrm{H}$ is obliged to maintain his wife during their marriage and for a period of three months after talaaqi. It is, therefore, clear that $\mathrm{H}$ and $\mathrm{W}$ agreed (in terms of their marriage contract) that $\mathrm{H}$ would maintain $\mathrm{W}$ during their marriage and for three months after talaaqi, and that any unpaid maintenance would accumulate as a debt and that the prescription of such a debt would not be possible. The court held, however, that prescription is for the benefit of the general public and that an agreement to renounce prescription (as in this case) would be against public policy. Therefore, $\mathrm{H}$ is only liable to pay maintenance to W for the period from 25 October 1991 (i.e. three years before W's counterclaim was served on H's attorneys) to 14 January 1993 (i.e. three months after the marriage was terminated by the third talak).

52 At $714 \mathrm{G}-\mathrm{H}$. $\mathrm{H}$ and $\mathrm{W}$ had to lead evidence regarding H's conduct regarding the divorce before the issue could be decided.

53 W's counsel argued that W was entitled to an equitable portion of H's estate. He based his argument on legislation enacted in Malaysia, that is section 58 of the Malaysian Islamic Family Law (Federal Territory) Act 1984 that confers upon a court the power to order a division of assets between divorcing parties (715D717A). The court did not accept his argument and held: "It is clear, in my view, that the Malaysian rules are based, in part at least, on Malay custom which, not being in conflict with the essential principles of Islamic law, is capable of being synthesised therewith. In view of the fact that no other Islamic country ... adopts this approach, I cannot see on what basis I can regard the Malaysian rules as being part of the provisions of Islamic personal law incorporated by the parties into their contract unless a custom similar to the Malay adat relating to harta sepencarian prevails among the Islamic community to which the parties belong in the Western Cape" (717B-D). 
recognised as valid. Secondly, the court did not deal with polygamous Islamic marriages and it is uncertain whether the court would have followed the same route if the marriage was in fact polygamous. Thirdly, it was a decision of the Cape Provincial Division and the possibility exists that other provinces might follow a different route because of the rule of stare decisis.

This was what in fact happened in Amod $v$ Multilateral Motor Vehicle Accident Fund 199712 BCLR 1716 (D), which was a decision of the Durban high court. The facts of the case were as follows: $\mathrm{H}$ and $\mathrm{W}$ entered into an Islamic marriage in 1989. Their marriage did not comply with the requirements of the Marriage Act and was, therefore, not regarded as a valid civil marriage. $\mathrm{H}$ was killed in a motor accident in 1993 and $\mathrm{W}$ lodged a claim for compensation against the Multilateral Motor Vehicle Accident Fund (MMF) for loss of support by reason of H's death. The MMF denied liability due to the fact that the marriage between $\mathrm{H}$ and $\mathrm{W}$ was a void Islamic marriage. $\mathrm{W}$ contended that $\mathrm{H}$ had a contractual obligation to support her. 54

The question before the court was whether the MMF was legally liable to compensate $\mathrm{W}$ for her loss of support. In terms of South African common law, such a liability would exist if $\mathrm{H}$ were, during his life, under a common law duty to support W. In terms of section 31 of the Black Laws Amendment Act 76 of 1963 a partner in a customary marriage may also claim for loss of support as a result of the death of the breadwinner. However, due to the Ismail case, which held that Islamic marriages were contra bonos mores, such a duty did not exist if the parties had been married in terms of Islamic law.

W's counsel argued, first of all, that there had been a change in public policy regarding the conclusion of Islamic marriages that had changed the traditional position. Meskin $\mathrm{J}$ found, however, that the onus to prove such a change rested on $\mathrm{W}$ and that she could not prove that there had been a change of policy since the Ismail case.

Secondly, W's counsel argued that the court should develop the common law to recognise a duty to support arising out of an Islamic marriage (section 39(2) read with sections 8(2) and (3) of the 1996 Constitution). Meskin $\mathrm{J}$ held that, although the facts of the case

54 In terms of an Islamic marriage, which is a contract, $\mathrm{H}$ is obliged to support and maintain $\mathrm{W}$. 
occurred before the commencement of the 1996 Constitution, it was in the interest of justice to apply the 1996 Constitution to the facts of the case. He interpreted sections 39(2), 8(2) and 8(3) of the 1996 Constitution and came to the conclusion that section 39(2) does not allow courts the general power to develop common law "to promote the spirit, purport, and objects of the Bill of Rights". The court argues that if section 39(2) is read with sections 8(2) and (3), it is clear that the development of the common law the legislature had in mind is development

... in order to give effect to a right in the Bill ... to the extent that legislation does not give effect to that right ... It is not intended that the Court is to have a general power of development of the common law to 'promote the spirit, purport and objects of the Bill of Rights' independently of giving effect, when applying a provision of the Bill of Rights to a natural or juristic person, to 'a right in the Bill $\ldots$ to the extent that legislation does not give effect to that right'55.

W's counsel argued that that the right to equality (section 9 of the 1996 Constitution) that includes the right not to be unfairly discriminated against on the grounds of marital status or religion, and the right to dignity (section 10 of the 1996 Constitution) are relevant to the facts of the case. Taking the facts of the case into consideration, Meskin $\mathrm{J}$ agreed that "a refusal to recognise the contractual duty of support upon which [W] relies as being sufficient to ground the liability which she seeks to enforce constitutes, indeed, a violation" of these rights. He agreed that such refusal would result in the unequal treatment of persons before the law, that is between females lawfully married in terms of the civil law to a deceased breadwinner and those married illegally to a deceased breadwinner in terms of non-recognised Islamic law. Although such refusal could result in the unequal treatment before the law, the question is whether the court has the power to develop common law by the elimination of a principle that already forms part of it. With reference to Du Plessis v De Klerk 19965 BCLR 658 (CC)56 Meskin J held:

Section 8(3)(a). 1722H-J. In Langemaat v Minister of Safety and Security 19984 BCLR 444 (T) Roux $\mathrm{J}$ held that the time has arrived for the recognition of a reciprocal duty of support owed by parties to a same-sex union. Such recognition is in accordance with the court's duty to promote the spirit, purport and objects of the Bill of Rights when developing common law $(448 \mathrm{H}-\mathrm{J})$. 
As I read section 8(3)(a), the intention is that if there is silence in the common law with regard to the giving effect to a right in the Bill, and legislation does not give effect to such right, the court must amplify the common law to eliminate such silence. This is not an intention that the court must, in order to give effect to a particular right, eliminate or alter an existing principle of the common law which affects the operation of such right, irrespective of the manner in which this occurs. The intention is that such alteration or elimination is to remain the function of the legislature (own emphasis - CR).

The court finally came to the conclusion that it may not alter the existing law regarding a claim for loss of support to include a duty to support in terms of a contractual relationship resulting from an Islamic marriage and W's claim was denied. $\mathbf{5 7}$

It is clear from the judgement that the court read its power to develop the common law as restrictive, i.e. not to eliminate principles that already form part of it. Such an attitude creates the impression that the courts, that are supposed to be the protectors of fundamental rights, are powerless to enforce or to protect those rights contained in the Bill of Rights. The 1996 Constitution provides the opportunity to adapt common law to give recognition to Islamic marriages. This developmental function of the courts should not be read as restrictive, i.e. to eliminate common law, but to adapt it to new circumstances. The distinctive character of common law has always been its ability to change through the ages. However, if it is not kept in mind that the change will not always be acceptable to the community, it will be mere paper law. This may also be one of the reasons why courts are reluctant to interfere with de facto situations and why they leave it to the legislature to effect change. Courts may, however, not ignore their duty as protector of an individual's fundamental rights in terms of the 1996 Constitution, by leaving it to the legislature to effect change.

Another disappointing aspect of the decision is the court's approach regarding an individual's constitutional right to equality. Surely the unequal treatment of married Muslim and other couples cannot be proven to be fair as envisaged in terms of section 9(5)?

$57 \quad$ The court distinguished the issues of this case from the issues present in Ryland $v$ Edros 19972 SA 690 (C) and correctly held on 1726E that the court in Ryland $v$ Edros 19971 BCLR 77 (C) did not hold that a Islamic marriage is a lawful marriage or that it generated a legal duty to support a wife. 
After the decision in Amod $v$ Multilateral Motor Vehicle Accident Fund 199712 BCLR 1716 (D) had been delivered, W applied for leave to appeal directly to the constitutional court.58 The constitutional court found that the crucial question in the application before the court was whether the common law should be developed to allow the applicant to claim damages for support. Since it was the viewpoint of the constitutional court that this question is one which falls primarily within the jurisdiction of the supreme court of appeal, the application for leave to appeal was dismissed. Although it could not be said that the constitutional court was misdirected in its findings, the reluctance (or caution) of courts to apply the Bill of Rights directly to private relationships is illustrated.

The facts of the case were then considered by the supreme court of appeal in Amod $v$ Multilateral Motor Vehicle Accidents Fund (Commission for Gender Equality Intervening) 19994 SA 1319 (SCA). (For a discussion of the issues raised in the case see Rautenbach \& Du Plessis, 2000:302-314.) On behalf of the appellant and the Commission for Gender Equality, it was argued that common law rules make provision for a claim for loss of support of a Muslim widow. In the alternative, it was argued that if the rules of common law do not make such provision, common law should be developed in terms of section 35(3) of the 1993 Constitution.59

The MMF alleged that an Islamic marriage does not enjoy the same status as a civil marriage, that the duty to support was a "contractual consequence of the union between them and not an ex lege consequence of the marriage per se" and that the action for loss of support should not be extended to include claims for loss of support pursuant to a contractual duty to furnish support. The action for loss of support, it was argued, should be restricted to cases in which the duty of support is one of the common law consequences of a valid marriage.

The court found that the appellant had a good cause of action, based on the fact that the deceased had a legally enforceable duty to support the appellant. The duty arose from a solemn marriage in accordance with the tenets of a recognised and accepted faith and that it was a duty that deserved protection and recognition for the

$58 \quad$ Amod v Multilateral Motor Vehicle Accidents Fund 19984 SA 753 (CC).

59 See par [5]. The 1993 Constitution was in effect when the action commenced in the court a quo. 
purposes of the dependant's action. The question was not whether the marriage was lawful at common law, but whether the deceased had a duty to support the appellant during the subsistence of the marriage. The court based its findings on an "important shift in the identifiable boni mores of the community" that "must also manifest itself in a corresponding evolution in the relevant parameters of application in this area," (at Par [23]) and on the test laid down in Santam Bpk $v$ Henery 19993 SA 421 (SCA). The court stated the following with regard to the non-recognition of an action for loss of support in the case of a monogamous Islamic marriage:

It is inconsistent with the new ethos of tolerance, pluralism and religious freedom which had consolidated itself in the community even before the formal adoption of the interim Constitution on 22 December 1993 (at Par [20]). ...

The inequality, arbitrariness, intolerance and inequity inherent in such a conclusion would be inconsistent with the new ethos which prevailed on 25 July 1993 when the cause of action in the present matter commenced (at Par [23] - CJR).

The court did not find it necessary to discuss the application of section 35(3) of the 1993 Constitution or section 39(2) of the 1996 Constitution, as it was able to reach its conclusion without reliance on those provisions.

The effect of this case is limited in two ways. Firstly, no recognition has been given to Islamic marriages. It is only the claim of a surviving spouse (married in terms of common law) for loss of support that has been extended to spouses married in terms of unrecognised Islamic personal law. Secondly, the court did not deal with polygamous Islamic marriages and it is uncertain whether spouses involved in such marriages would receive similar protection. It is, therefore, suggested that legislative recognition of Islamic marriages be given.

\subsection{Legislative recognition of Islamic marriages}

In the previous paragraphs it was illustrated that courts are reluctant to develop common law to recognise Islamic marriages. Furthermore, the Bill of Right's scope of application to common law is uncertain. 60 A second option is to allow for the legislative recognition of Islamic personal law.

60 With regard to the application of the Bill of Rights to common law, it is argued that section 8 of the 1996 Constitution does not necessarily support the direct 
Unofficial religious legal systems or, at least, marriages concluded under a "system of religious, personal or family law" in South Africa must receive legislative recognition in terms of the 1996 Constitution.61 Such recognition would ensure that the Bill of Rights applies to customs and usages followed by religious communities and that the necessary constitutional protection is afforded to women within these communities. There are already numerous Acts in South Africa that recognise certain aspects of Islamic marriages, for example:

- Section 21(3) of the Insolvency Act 24 of 1936 describes the word "spouse" to include also a wife or husband married "according to any law or custom".

- Section 31 of the Special Pensions Act 69 of 1996 defines "dependant" to include the spouse of a deceased to whom he or she was married "under any Asian religion".

- Section 1 of the Demobilisation Act 99 of 1996 defines "dependant" to include the surviving spouse to whom the deceased was married "in accordance with the tenets of a religion".

- Section 1(2)(a) of the Births and Deaths Registration Act 51 of 1992 includes in the word "marriage" all marriages contracted according to the "tenets of any religion".

Although it may be argued that this legislation recognises Islamic marriages for practical reasons, it is indicative of the plurality of the South African society. It is difficult to justify why Islamic marriages are recognised for certain purposes, but not when the parties of an Islamic marriage turn to the courts for the recognition of their union.

Another reason why religious legal systems should be recognised concerns the developmental function of courts. Courts have the

application of the Bill of Rights to private disputes in terms of common law. It is argued that various provisions of the 1996 Constitution support the indirect horizontal application of the Bill of Rights to common law. For a discussion of the arguments in favour of such an inference, see Rautenbach (2001:303 et seq).

61 Section 15(3) reads: "(a) This section does not prevent legislation recognising (i) marriages concluded under any tradition, or a system of religious, personal or family law; or (ii) systems of personal and family law under any tradition, or adhered to by persons professing a particular religion. (b) Recognition in terms of paragraph (a) must be consistent with this section and the other provisions of the Constitution." 
power to develop common law and customary law. They do not have similar powers regarding unrecognised religious legal systems. It would, therefore, be difficult, if not impossible, for courts to adapt any customs and usages adhered to as unofficial law in South Africa. Even if courts had the power to develop the legal rules of the religious communities, it is doubtful whether these communities would tolerate judicial interference with their customs and usages (Rautenbach, 2002:118).

The recognition of Islamic personal law or Muslim marriages must be consistent with the Bill of Rights contained in the 1996 Constitution. The implication is that Islamic personal law will only be recognised to the extent that it conforms to the spirit, purport and objects of the Bill of Rights. The drafting of legislation that recognises Islamic personal law or at least Islamic marriages will not be an easy task. There are numerous areas of potential conflict. From a Western point of view, Islamic personal law often discriminates against women. 62 For example, a women inherits only half of what her male counterpart inherits (see Cachalia, 1991:30); it is easier for a husband to divorce his wife than for a wife to divorce her husband63; a wife does not participate in the marriage ceremony and a husband may marry more than one wife whilst a wife may only marry one husband64. If all "discrimination" is not eliminated, the recognition of Islamic personal law by means of legislation will not be in compliance with the provisions of the 1996 Constitution.

\subsection{Draft Bill on Islamic Marriages}

The South African Law Commission (SALC) has been involved in the investigation of Islamic personal law since 1990 (Project 59). The first project committee that was appointed did not make much progress with the investigation. The reasons for the delay are not very clear. It seems as if the finalisation of the 1996 Constitution and a divergence of opinion on contentious issues are some of the

62 Discrimination against women is by no means typical of religiously based personal law systems. South African common law was, until recently, also guilty of discrimination against women. However, the most blatant forms of discrimination were removed by the legislature. For example, in 1993, the General Law Fourth Amendment Act 132 of 1993 abolished the marital power of a husband over his wife and the Prevention of Family Violence Act 133 of 1993 provides for the prosecution of marital rape for the first time. 
reasons that could be advanced. The SALC did not publish any of its findings for discussion.

In 1996, the SALC showed renewed interest in the investigation. It decided to accord the investigation a high priority rating and recommended the appointment of a project committee. During March 1997 the SALC held two workshops in order to involve members of the public and interested parties. From 78 nominations received, the previous Minister of Justice appointed a new project committee who, under the leadership of Justice Navsa, issued its first discussion document at the end of May 2000 - Issue Paper 1565. According to the SALC, its aim is to "investigate the legal recognition of Islamic Marriages and other aspects of Islamic Personal Law". As a result of Issue Paper 15, various responses from interested parties were received and considered by the SALC. The comments were published at http://www.law.wits.ac.za/salc/ issue/issue.html.

At the end of 2001 the SALC published Discussion Paper 101 (SALC Discussion Paper 101, 2001). The closing date for comments was 31 January 2002. The discussion document contains a proposed Draft Bill on Islamic Marriages. The purpose of the draft Bill is to recognise existing monogamous and polygamous Islamic marriages. 66 The Draft Bill makes provision for, inter alia, the recognition of Islamic marriages in South Africa (clause 4), the requirements for a valid Islamic marriage 67 , the registration68, proprietary consequences 69 and dissolution 70 of Islamic marriages

65 SALC Issue Paper 15 (2000). The closing date for comments was the end of July 2000.

66 In terms of clause 1 of the draft Bill "Islamic marriage" means a marriage "contracted in accordance with Islamic law only". It excludes a civil marriage concluded in terms of the Marriage Act. The parties may, however, elect to cause the provisions of the draft Bill to apply to the civil marriage.

67 Clause 5 deals in essence with the minimum age of marriage which is eighteen years of age, and the issue of consent by the parties.

68 Clause 6 makes provision for the recognition of existing and new Islamic marriages. However, the failure to register an Islamic marriage does not affect the validity of a marriage.

69 The proprietary consequences of a marriage are dealt with in clause 8 . A marriage is automatically out of community of property, except if the spouses entered into a contractual arrangement in terms of which they mutually agree to another marriage regime. 
and the status and capacity of spouses in Islamic marriages (clause 3 ). Custody and access to children are based on the principle of the best interest of the child and are dealt with in clause 11. Clause 14 has specifically been inserted to deal with the situation where the parties were married in terms of civil and Islamic law. An Islamic marriage must be dissolved prior to the dissolution of a civil marriage. This is to avoid the hardships caused by the dissolution of a civil marriage whilst an Islamic marriage still exists. In terms of clause 12, the Maintenance Act 99 of 1998 apply to Islamic marriages.

All responses received up to and including 10 April 2000 were published by the SALC in a special document referred to as "Collation of Submissions on Discussion Paper 101: Islamic and Related Matters".71 The general viewpoint is that the Draft Bill will alleviate the hardships that existed as a result of the non-recognition of Islamic marriages. However, concerns exist regarding the nonsupport of the Draft Bill among some groupings of the Muslim community. Up to date no legislation has been published in this regard.

Although the SALC is currently investigating the recognition of Islamic marriages only, the possibility is not excluded that other religious communities will soon follow.

\section{Concluding remarks}

Islamic marriages and Islamic personal law are not recognised in terms of South African common law. The 1996 Constitution gives courts the opportunity to adapt common law to "promote the spirit, purport, and objects of the Bill of Rights" (Section 39(2)). The development function of courts should not be read as restrictive, that is to eliminate common law, but to adapt it to new circumstances. The distinctive character of common law has always been its ability to adapt to changing circumstances.

The 1996 Constitution recognises, among other rights, the cultural diversity of South Africa by protecting cultural and religious rights. Such change in public policy regarding the recognition of cultural

70 Clause 9 recognises the dissolution of a marriage on any ground permitted by Islamic law. Provision is made to register an irrevocable talaq that must be confirmed by a court in order to be effective. 
diversity in South Africa should be reflected in the decisions of courts. Courts should not ignore their newly-found duty as protector of an individual's fundamental rights by leaving it to the legislature to effect change. Undoubtedly courts are placed in a difficult position. If they develop common law to recognise Islamic marriages as valid marriages, it may lead to discrimination against women. On the other hand, if they do not recognise Islamic marriages as valid marriages, they do not afford equal legal protection to Muslims.

The 1996 Constitution makes provision for the recognition of traditional and religious marriages and traditional and religious personal law systems by means of legislation. In order to reach legal certainty regarding the validity of Islamic marriages, legislative recognition should be given to legalise Islamic marriages in South Africa. The Recognition of Customary Marriages Act (120 of 1998) serves as an example of such an act.

The new dispensation brought about by the 1996 Constitution has introduced a particular perspective regarding the recognition of Islamic marriages. A pluralistic society such as South Africa would pose an enormous challenge to ensure vis-à-vis the constitutional court that the values enshrined in the Bill of Rights are to be enforced, and apply to all citizens. On the other hand, the seemingly discriminatory laws are based on values that are not subject to censure on any ground whatsoever. It is important that Muslim women participate in the SALC's investigation into Islamic marriages in order to ensure that their rights are in no way compromised in favour of religious and cultural freedoms and rights.

\section{List of references}

CACHALIA, F. 1991. The future of Muslim Family Law in South Africa. Johannesburg: WITS Centre for Applied Legal Studies. Occasional Paper 12.

CENTRAL STATISTICAL SERVICE. 1991. Report 03/01/22 Population Census. Pretoria.

CLARK, B. 1989. History of the Roman-Dutch law of marriage from a socioeconomic perspective. (In Visser, D.P., ed. Essays on the History of Law. Cape Town: Juta. p. 152-212.)

CORBETT, M.M., HAHLO, H.R. \& HOFMEYR, G.Y.S. 1980. The Law of Succession in South Africa. Kaapstad: Juta.

CRONJÉ, D.S.P. \& HEATON, J. 1999. South African Family Law. Durban: Butterworths.

DE WAAL, J., CURRIE, I. \& ERASMUS, G. 2001 The Bill of Rights Handbook. Kenwyn: Juta. 
GOOLAM, N.M.I. 1996. Gender equality in Islamic family law. (In "Law in Motion". Paper delivered at the 1st World Law Conference 9-12 September 1996. Brussels: Conference Papers. p. 752-753.)

HAHLO, H.R. 1963. The South African Law of Husband and Wife. Cape Town: Butterworths.

HAHLO, H.R. 1985. The South African Law of Husband and Wife. Cape Town: Juta.

HARON, M. 1997. Muslims in South Africa: An annotated bibliography. Cape Town: South African Library.

KLEYN, D. \& VILJOEN, F. 2002. Beginners guide for law students. Kenwyn: Juta.

MAHOMED, A. 1997. Ryland v Edros [1996] 4 All SA 557 (C). De Rebus, 350: 189.

MOOSA, N. 1998. The interim and final Constitutions and Muslim Personal law: Implications for South African Muslim women. Stellenbosch Law Review, 9(2):198.

MOOSA, V.I. 1995. A fundamental document of human motivation, relationships and human endeavours from an Islamic perspective.

http://www.constitution.org.za/cgi-bin/vdkw-cgi/xfee016d6-327/Search/ x334384/9\#HLO [23 May 1995. p. 19-22].

MOOSA, N. 1996. An analysis of the human rights and gender consequences of the new South African Constitution and Bill of Rights with regard to the recognition and implementation of Muslim Personal Law (MPL). Bellville: UWC. (LL.M.-thesis.)

RAUTENBACH, I. 2000. The Bill of Rights applies to Private Law and binds Private Persons. Tydskrif vir Suid-Afrikaanse Reg, 2:303-304.

RAUTENBACH, C. \& DU PLESSIS, W. 2000. The extension of the dependant's action for loss of support and the recognition of Muslim marriages: the saga continues: Amod v Multilateral Vehicle Accidents Fund (Commission for Gender Equality Intervening). Tydskrif vir Hedendaagse Romeins-Hollandse Reg, 63(2):302-314

RAUTENBACH, C. 2002. Application of the South African Constitution to unrecognised religious legal systems. (In Rautenbach, C. \& Goolam, N.M.I., eds. Introduction to legal pluralism in South Africa: Religious legal systems. Durban: Butterworths. p. 115-118.)

RAUTENBACH, C. 2001. The position of South African women under the Law of Inheritance. Potchefstroom: PU for CHE. (LL.D. Thesis.)

SALC

see SOUTH AFRICAN LAW COMMISSION

SOUTH AFRICAN LAW COMMISSION. 2001. Discussion Paper 101 on 59 on Islamic Marriages and Related Matters (Project 59). Pretoria.

SOUTH AFRICAN LAW COMMISSION. 2000. Issue Paper 15 on Islamic Marriages and Related Matters (Project 59). Pretoria.

SINCLAIR, J.D. 1996. The Law of Marriage. Kenwyn: Juta.

\section{Case law}

Allen $v$ Gibbs 19773 SA 212 (SE)

Amod v Multilateral Motor Vehicle Accidents Fund 19984 SA 753 (CC)

Amod $v$ Multilateral Motor Vehicle Accident Fund (Commissioner for Gender

Equality Intervening) 19994 SA 1319 (SCA) 
Amod v Multilateral Motor Vehicle Accident Fund 199712 BCLR 1716 (D)

Bronn v Frits Bronn's Executors (1860) 3 Searle 313

Davids $v$ The Master 19831 SA 458 (C)

Du Plessis v De Klerk 19665 BCLR 658 (CC)

Esop v Union Government (Minister of the Interior) 1913 CPD 133

Ex Parte Azar 1932 OPD 107

Ex Parte L 19473 SA 50 (C)

Ismail $v$ Ismail 19831 SA 1006 (A)

Langemaat $v$ Minister of Safety and Security 19984 BCLR 444 (T)

Mashia Ebrahim v Mahomed Essop 1905 TS 59

Moola v Aulsebrook NO 19831 SA 687 (N)

$R$ v Fatima 1912 TPD 59

$R v$ Sukina 1912 TPD 1079

Ryland v Edros 19971 BCLR 77 (C)

$S v$ Johardien 19901 SA 1026 (C)

Santam Bpk v Henery 19993 SA 421 (SCA)

Seedat's Executors $v$ The Master (Natal) 1917 AD 302

Solomons $v$ Abrams 19914 SA 437 (W)

\section{Legislation}

Admission of Persons to the Republic Regulation Act 59 of 1972

Admission of Persons to the Union Regulation Act 22 of 1913

Admission of Persons to the Union Regulation Amendment Act 60 of 1961

Aliens Control Act 96 of 1991

Births and Deaths Registration Act 51 of 1992

Births and Deaths Registration Amendment Act 40 of 1996

Black Laws Amendment Act 76 of 1963

Constitution of the Republic of South Africa 108 of 1996

Constitution of the Republic of South Africa 200 of 1993

Criminal Procedure Act 51 of 1977

Demobilisation Act 99 of 1996

General Law Amendment Act 80 of 1971

General Law Fourth Amendment Act 132 of 1993

Immigrants Regulation Act 22 of 1913

Immigration Act 30 of 1906 (C)

Indian Immigration Law 25 of $1891(\mathrm{~N})$

Indian Relief Act 22 of 1914

Insolvency Act 24 of 1936

Intestate Succession Act 81 of 1987

Law 19 of $1881(\mathrm{~N})$

Law of Evidence Amendment Act 45 of 1988

Maintenance Act 99 of 1998

Malaysian Islamic Family Law (Federal Territory) Act 1984

Marriage Act 16 of 1860 (C)

Marriage Act 25 of 1961

Natal Act 35 of 1905

Prevention of Family Violence Act 133 of 1993

Recognition of Customary Marriages Act 120 of 1998

Special Pensions Act 69 of 1996 


\section{Kernbegrippe:}

Moslemhuwelike

Grondwet van 1996

fundamentele regte

gelykheid en erkenning van Moslem Persoonlike Reg

\section{Key concepts:}

Muslim marriages

Constitution of 1996

fundamental rights

equality and recognition of Muslim Personal Law 